


\title{
Notes on the vocalizations of Slaty-capped Shrike-vireo (Vireolanius leucotis)
}

Peter Boesman

In the following we briefly analyze and compare voice of the different races of Slaty-capped Shrike-vireo (Vireolanius leucotis). We also try to quantify the extent of any vocal differences using the criteria proposed by Tobias et al. (2010), as a support for taxonomic review. We have made use of sound recordings available on-line from Xeno Canto (XC).

Song of all races is structurally the same: a single loud melodious whistle endlessly repeated. This whistle is however slightly different among races (fig. 1):

$\begin{array}{lccc}\text { V. I. mikettae (W Colombia (S of R San Juan) and W Ecuador (S to NW Azuay)) } \\ \mathrm{n}=8 & \text { range } & \text { average } & \text { SD } \\ \text { start freq. } & 2700-3100 \mathrm{~Hz} & 2876 \mathrm{~Hz} & 176 \mathrm{~Hz} \\ \text { end freq. } & 1760-2300 \mathrm{~Hz} & 2141 \mathrm{~Hz} & 163 \mathrm{~Hz} \\ \text { freq. drop in main part } & 0-120 \mathrm{~Hz} & 54 \mathrm{~Hz} & 40 \mathrm{~Hz} \\ \text { length } & 0.66-0.84 \mathrm{~s} & 0.75 \mathrm{~s} & 0.06 \mathrm{~s}\end{array}$

V. I. leucotis (S Venezuela (Bolívar, Amazonas) and the Guianas S to N Brazil (N of Amazon); extreme S Colombia (SE Nariño), E Ecuador and N Peru (S to San Martín)).

$\begin{array}{llll}\mathrm{n}=15 & \text { range } & \text { average } & \mathrm{SD} \\ \text { start freq. } & 2500-2920 \mathrm{~Hz} & 2705 \mathrm{~Hz} & 152 \mathrm{~Hz} \\ \text { end freq. } & 1750-2000 \mathrm{~Hz} & 1892 \mathrm{~Hz} & 65 \mathrm{~Hz} \\ \text { freq. drop in main part } & 200-470 \mathrm{~Hz} & 360 \mathrm{~Hz} & 84 \mathrm{~Hz} \\ \text { length } & 0.48-0.65 \mathrm{~s} & 0.55 \mathrm{~s} & 0.06 \mathrm{~s}\end{array}$

V. I. simplex (E Peru (Huánuco S to Ayacucho and Cuzco) and NC Brazil S of Amazon (R Purús E to R Tocantins, $S$ to NW Mato Grosso))

V. I. bolivianus (SE Peru (Cuzco) S to NC Bolivia (La Paz, Cochabamba and Santa Cruz)).

$\mathrm{n}=12$

start freq.

end freq.

freq. drop in main part

length average $\quad \mathrm{SD}$

$2718 \mathrm{~Hz} \quad 172 \mathrm{~Hz}$

$1693 \mathrm{~Hz} \quad 118 \mathrm{~Hz}$

$560 \mathrm{~Hz} \quad 145 \mathrm{hz}$

$0.60 \mathrm{~s} \quad 0.12 \mathrm{~s}$

Effect size calculation:

end freq.

freq. drop

length mikettae vs. leucotis

2.0

4.65

3.33 mikettae vs. simplex

3.15

4.76

1.58 leucotis vs simplex

1.69

0.53 


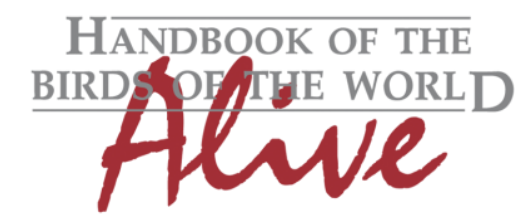

\section{ORNITHOLOGICAL NOTES}

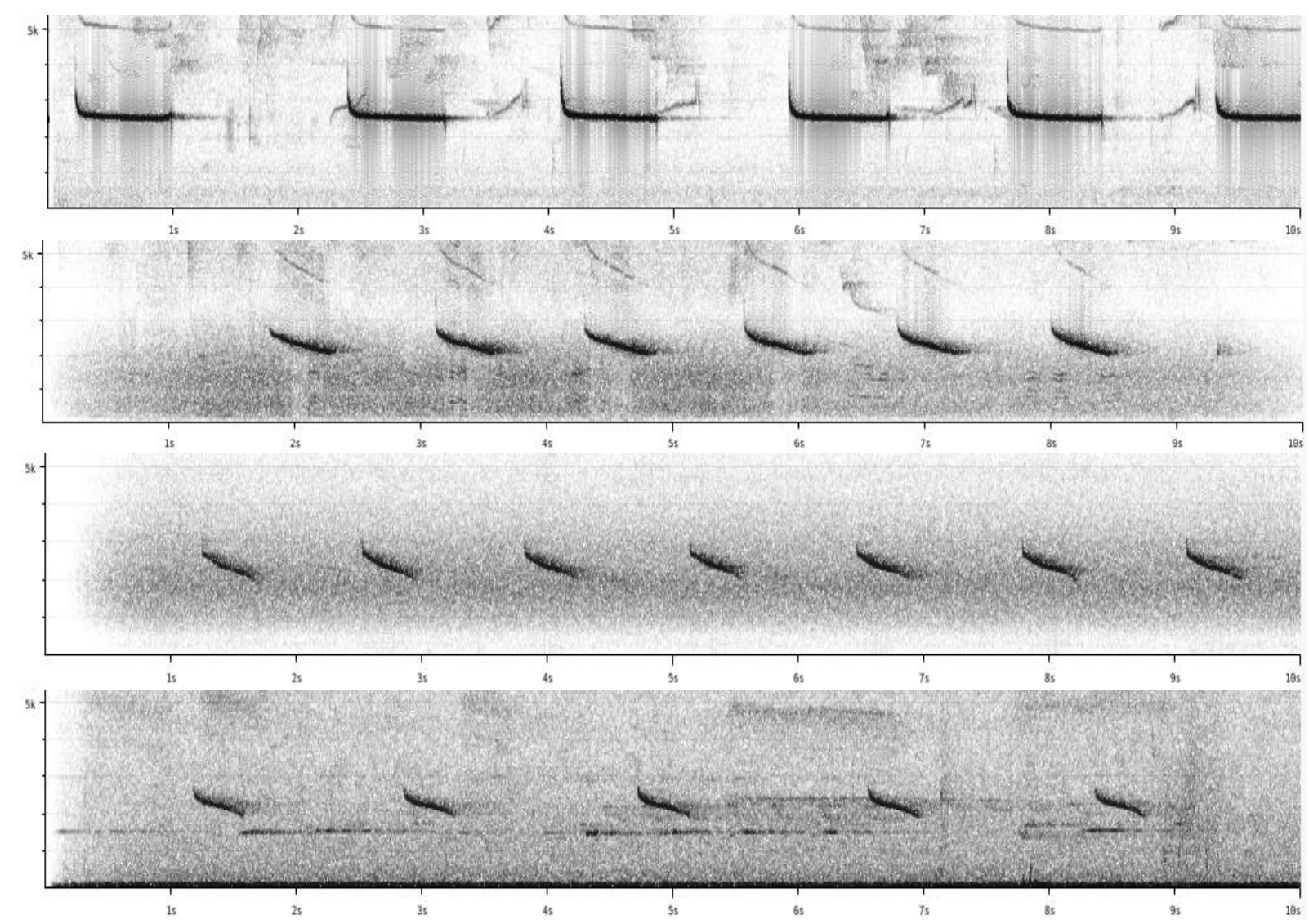

Figure 1:top to bottom: typical example of song of mikettae, leucotis, simplex and bolivianus.

When applying Tobias criteria, this translates in the following vocal scores:

\begin{tabular}{|c|c|c|c|}
\hline & e vs. leucotis & mikettae vs. simplex & leucotis vs simplex \\
\hline end freq. & 2 (just) & 2 & 2 (just) \\
\hline freq. drop & 2 & 2 & 1 \\
\hline length & 2 & 1 & 1 \\
\hline TOTAL VOCAL SCORE & 4 & 4 & 3 (just) \\
\hline
\end{tabular}

mikettae has a whistle which hardly drops in pitch (between about $10 \%$ and $90 \%$ of its length), as a consequence reaches not that low frequencies. Whistle is also longer in length. $->$ total score of 4 vs both other races

leucotis is closer to simplex/bolivianus, but its whistle drops less in frequency, and as a consequence doesn't reach that low frequencies, although there is some overlap. $\rightarrow$ total score 3 at most (may be reduced to 2 with larger set of recordings)

This note was finalized on 19th October 2015, using sound recordings available on-line at that moment. We would like to thank in particular the many sound recordists who placed their recordings for this species on XC. 


\section{References}

Tobias, J.A., Seddon, N., Spottiswoode, C.N., Pilgrim, J.D., Fishpool, L.D.C. \& Collar, N.J. (2010). Quantitative criteria for species delimitation. Ibis 152(4): 724-746.

\section{Recommended citation}

Boesman, P. (2016). Notes on the vocalizations of Slaty-capped Shrike-vireo (Vireolanius leucotis). HBW Alive Ornithological Note 167. In: Handbook of the Birds of the World Alive. Lynx Edicions, Barcelona. (retrieved from http://www.hbw.com/node/932097 on 19 August 2016). 